\title{
Developing Role Play Game for Mathematics based on Guided Inquiry Approach with ADDIE model
}

\author{
Ahmad Akrom Nur Fuqoha \\ Master Program of Mathematics Education \\ Sebelas Maret University \\ Surakarta, Indonesia \\ ahmadakrom001@gmail.com
}

\author{
Diari Indriati \\ Department of Mathematics \\ Sebelas Maret University \\ Surakarta, Indonesia
}

\begin{abstract}
This research aims to describe how to develop RPG game as learning media that considered the three quality aspects (validity, practically, and effectiveness). This research conduct Research and Development model (R\&D). ADDIE model is adopted as a juncture of developing RPG game that consists of the process that is made up of Analyze, Design, Development, Implementation, and Evaluation phases. Data were got from observation, evaluation of test and non-test to assess the quality of the product. As the instruments of the study, they are validity expert judgment questionnaire, practically questionnaire, observation sheet and student worksheet of the effectiveness. Based on the results, obtained that the RPG game got a 4.17 from the media experts, so it was very valid. The media also got 4.63 from teacher and student's questionnaire results, so it was very practical. Student completeness after using media was $86.7 \%$, so it was to be effective. So, the learning media in the form of RPG game had a good quality.
\end{abstract}

Keywords-learning media; mathematics; RPG game; guided inquiry; $A D D I E$

\section{INTRODUCTION}

Technology is not just employed exclusively for an activity. In the last decade, a researcher had deployed the use of technology for any activities, one of them was for the educational purpose. Many discoveries for education purpose that can improve the quality of education. Students are now getting a lot of convenience because of the rapid technological advancement. They can use their smartphone to get the book that they are looking for. Therefore, they don't have to go to the library anymore. Moreover, they don't have to buy the book in the bookstore because play store has provided it. By using technology, everybody especially students can study anywhere and every time easily. It shows us that Information and Communication Technology (ICT) implementation is one of an important aspect of the other, like lesson subject [1].

On the other side, the teacher also got advantages by technology advances. They can access many websites on the internet that provide a lot of books, and also many kinds of exercises. In fact, there are already question banks that can be accessed by teachers. For certain subject teachers that have to perform several experiments, they can show it by using liquid crystal display (LCD). The video can be obtained on the internet. Operationally, it will help out teacher's duties. Thus the technology advancement made it all more practical and effective.

In fact, technology advancement is still underutilized by people. Most people don't use technology for learning activities but for the others (e.g. playing or business). Internet utilization for entertainment purposes such as opening social media was on top of the survey about internet usage activities with a $73.3 \%$ and for educational services was only $19.9 \%$ [2]. It shows that technology has not been utilized optimally. The low utilization of technology affects the quality of education indirectly. Based on the previous research, indicated that students' mathematical initial ability was low [3]. Therefore, it is necessary to be used to utilize technology in learning (e.g. using media based on technology as learning media).

The game as learning media is the right choice to attract students' attention because it is fun. It is not only fun but also increases student achievement and motivation [4][5]. It can be an alternative to mathematics learning media to improve mathematical reasoning abilities in the classroom [6]. The genre of game that allows students to learn by constructing their knowledge according to Curriculum 2013 (C-13) is role play game (RPG) genre. This curriculum focuses on student learning, which means learning is no longer focused at the activity of teachers so that the teachers do not always explain learning materials to the class [7]. As players in that game, students learn through these interactions (material, symbolic, and social), they develop design expertise, meaning they understand the basic and emergent properties of the system [8]. Students who learn to use guided inquiry more easily mastered the concept [9]. Researcher considers it necessary to develop learning media in the form of RPG based on guided inquiry approach. Thus, this research has the purpose to find out how to develop that media and to know the quality.

\section{RESEARCH AND METHOD}

RPG development refers to ADDIE models which consist of five phases, as follows: analysis, design, development, implementation, and evaluation [10]. The first stage is analysis, and it involved an analysis of curriculum, analysis of learning for mathematics, analysis of student characteristic and analysis 
of using technology. The second phase is designing, that consists of some instruments as follows: expert judgment sheet, student and teacher' questionnaire, observation sheet and RPG's scenario. Furthermore, RPG's design adapted to the guided inquiry approach. The development stage was developing an RPG media using computer software (e.g. Adobe Series and RPG Maker). The storyline in RPG was created based on the scenario. In this phase was getting some pieces of advice from the expert's judgment to know the mistake of the development. After getting the experts judgment, then RPG had a revision. The implementation stage, it was conducted in a junior high school with 31 students, a teacher, and 2 observers. Instruments were used in this phase consisted of student' exercise, observation sheet, student and teacher' questionnaire with a 5-grade LikertType ranging from "strongly agree" to "strongly disagree" and the comment column. The last phase of this model was an evaluation.

The type of data collected in this study consisted of qualitative and quantitative data. Qualitative data were obtained from the comment of expert judgment, student and teacher response, and observer comment. Quantitative data were obtained by expert judgment, student and teacher' questionnaire with a 5-grade Likert-type and also from observation sheet. It was used to know the quality of developed media. In order to make the concept "quality" more transparent, it was related to a typology of curriculum representations, resulting in a framework with three quality criteria: validity, practicality, and effectiveness [11]. Before getting the quality of media, the quantitative data should be converted to qualitative data (i.e. validity and practically) using the following Table 1 [12].

TABLE I. CONVERSION OF ASSESSMENT FOR ALL ASPECTS

\begin{tabular}{|l|l|l|}
\hline \multirow{2}{*}{\multicolumn{1}{|c|}{ Interval }} & \multicolumn{2}{c|}{ Criteria } \\
\cline { 2 - 3 } & \multicolumn{1}{|c|}{ Validity } & \multicolumn{1}{c|}{ Practicality } \\
\hline $\bar{x}>4.20$ & Very valid & Very practice \\
\hline $3.40<\bar{x} \leq 4.20$ & Valid & Pracice \\
\hline $2.60<\bar{x} \leq 3.40$ & Enough & Enough \\
\hline $1.79<\bar{x} \leq 2.60$ & Less & Less \\
\hline $\bar{x} \leq 1.79$ & Not valid & Not practice \\
\cline { 2 - 3 } & &
\end{tabular}

\section{RESULTS AND DISCUSSION}

Results of this study consisted of ADDIE's phase (i.e. analysis, design, development, implementation, and evaluation). The first phase consisted of curriculum analysis, analysis of mathematics learning using a computer, student characteristic, and technology. Analysis curriculum phase showed that RPG media was suitable to Basic Competencies 6.2 (i.e. identifying a characteristic of rectangle, square, and triangle) and 6.3 (i.e. finding circumference and area of square and triangle) in Curriculum 2013. They were chosen not only because of many forms of the geometry plane that can be used as a component of RPG but also there were students that couldn't imagine it clearly. Analysis of mathematics learning using computer showed that students interested to study mathematics using a computer and happy to learn by using a game. Technology and interactive media could attract and increase the motivation of learners [13]. Theory of student characteristic showed that 11 to 15 years old were informal operation stage [14], it means that students in junior high school though from what is to what might be and it was suitable with RPG's mindset. Children could resolve hypothetical situations because they were not dependent on the real thing and already had logical thinking.

Based on analysis of technology showed that development of RPG media used software Adobe Illustrator CS6, Adobe Photoshop CS6, Adobe Flash CS6 and RPG Maker VX Ace. Adobe series were used to create some pictures and videos and inserted into RPG Maker VX Ace. RPG Maker VX Ace had a smoother image the previous version, and for the beginners, it was easier to learn [15]. So that was the reason for using that version.

At the design phase, there was a preparation of media assessment instrument consisting of experts judgment sheet, student and teacher questionnaire, observation sheet and RPG scenario. There were 4 aspects of expert's judgment sheet as follows: quality of content and purpose; instructional quality; quality of technical and quality of visual communication [16] [17]. Each aspect had several different indicators and had 49 statements in total with a 5-grade Likert-Type. There were 7 aspects of the student questionnaire, as follows: happiness, curiosity, activity, concern, interest, passion, and simplicity [18]. There were 6 viewpoints of the teacher questionnaire, as follows: practically, clarity, curiosity, interest, passion, and simplicity. Observation sheet that had Guttman Skala (i.e. yes or no) was used in the observation by the observer to know the implementation of media usage [19]. The RPG scenario was created using Microsoft word by displaying location sett, event description, and conversations, that showed in Fig 1.

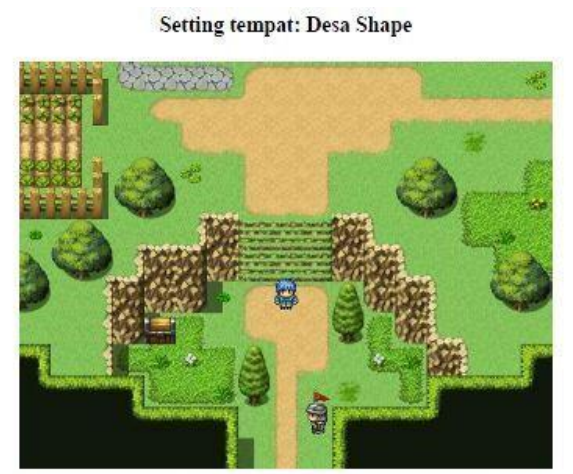

Angular menemui Penjaga Gerbang untuk menyerahkan Batu Jenis dan Sifat yang diperolehnya dari penduduk Desa Shape.

$\begin{array}{ll}\text { Angular } & \text { : Aku sudah mendapatkan Batu Jenis dan Sifat ini. } \\ \text { Penjaga Gerbang } & \text { : Apakah kamu melakukannya dengan baik? }\end{array}$

Fig 1. RPG' scenario

At the development stage, the plan was extended by using RPG Maker VX Ace that was helped by Adobe CS6 Series by the researcher. There were some parts of RPG game consisted of the introduction, the core, and the end of the game. In the 
introduction part, users could select options they want such as start, resume, instruction, purposes, about the game, and exit in the starting point. In the core, users became the main character who finished the story. The story will end if the main character solved all of the challenges and the exercises. The end section presented thanksgiving and said tank to all parties involved. After that, media was got a judgment from the expert to know the validity. The result of that assessment was showed in Table 2.

TABLE II. EXPERT JUDGMENT

\begin{tabular}{|l|l|l|}
\hline \multicolumn{1}{|c|}{ Aspect } & \multicolumn{1}{|c|}{ Mean } & \multicolumn{1}{c|}{ Criteria } \\
\hline Content and purpose quality & 3.80 & Valid \\
\hline Instructional quality & 4.10 & Very valid \\
\hline Technical quality & 4.20 & Very valid \\
\hline Visual comunication quality & 4.10 & Very valid \\
\hline $\begin{array}{l}\text { Conclusion: the quality of media categorise as Very Valid by a } \\
\text { bit of revision }\end{array}$ & \\
\hline
\end{tabular}

Based on that result, shows that media is very valid, with a 4.05 mean. Although it is very valid, doesn't mean there isn't advice by the experts. They gave some advice in the comment column for getting the better media. Parts of the game that need to be fixed, as follows: game navigation, game display to be full screen, replace the unclear pictures. Then, the researcher did revision using that result.

After developing media, then media was implemented in a class with 31 students and a teacher. The focus of this phase was to see the practicality and effectiveness of the RPG game as learning media. The practicality of RPG media was viewed by using the result of student and teacher questionnaire, and also from the level of implementation that was observed by 2 observers. The effectiveness was viewed from the student' achievement after finishing the exercise. In the beginning, students and teacher learn by using it. Students worked on a group when playing the game. In the end, they worked individually (i.e. when solving the exercise and filling the questionnaire).

Students and teacher filled questionnaire individually, and there was no time restriction for answering it. The result was showed in Fig. 2 and Fig. 3 to get the conclusion. With a 4.62 mean for student questionnaire and a 4.64 mean for teacher questionnaire showed that RPG game was very practical because of the mean of student and teacher response indicated a 4.63 mean. The practicality was also been strengthened by the level of implementation that showed a $94 \%$ for all aspects to get that. That level was obtained from the observation sheet that filled by observers.

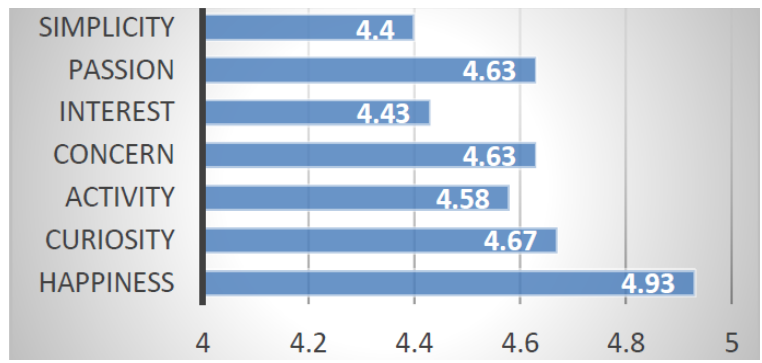

Fig 2. Result of student' questionnaire

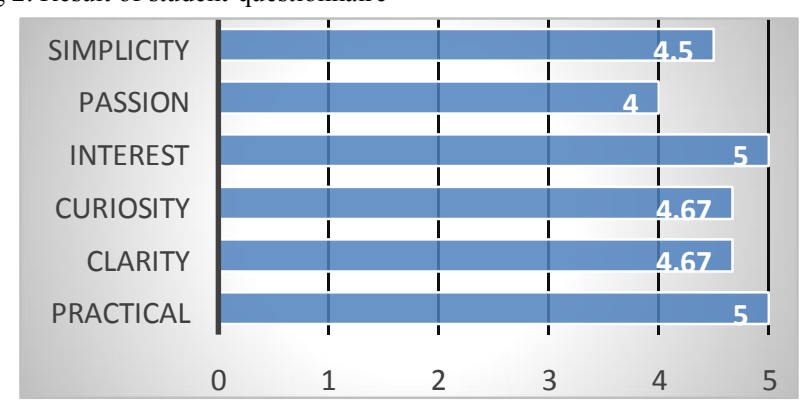

Fig 3. Result of teacher'questionnaire

Students learning results showed that they were able to get a score above the limitless. There were only 4 students who didn't exceed the limitless mastery of the exam from 30 students who take it or, $86.7 \%$ of students got a score above 75 after using RPG media. Because many students had exceeded the limit mastery, it said that RPG media was effective as learning media [19].

The last phase was an evaluation that conducted in each phase of development. The evaluation was revised by a researcher, according to suggestions. Those suggestions were obtained from expert judgment at the development phase and got from student and teacher comment from students and teacher at the implementation phase. Therefore, researcher fixed navigation that wasn't clear yet and changed the view to be fullscreen, same pictures that unclear. The evaluation phase was used to get the expected media.

\section{CONCLUSION}

The media had done by using ADDIE model to develop RPG as media of mathematics learning. The result of the expert judgment in term of content and purpose quality; instructional quality; quality of technical; and quality of visual communication showed that media was very valid, with a mean 4.17. Similarly, the result of student and teacher questionnaire was quite high with a 4.62 and 4.64 which supported by the result of the level of implementation (94\%) to show that RPG media was very practical. Furthermore, an average of the mastery level of students learning $(86.7 \%)$, showed that RPG media was very effective to be media of mathematics learning. Thus, RPG had good quality as media of mathematics learning in the junior high school, and the advice for the next research is the development of RPG media can be for the next grade. 


\section{REFERENCES}

[1] J. Soland, L. S. Hamilton, and B. M. Stecher, "Measuring 21st Century Competencies Guidance for Educators 21 ST CENTURY COMPETENCIES," Asia Soc. Glob. Cities Educ. Netw., pp. 68, November, 2013.

[2] Ministry of Communication and Information Technology Republic of Indonesia, 2016 Households and Individuals ICT Indicator Infographic. Jakarta: R\&D for Post \& ICT Resources, Equipment \& Operation, 2016.

[3] N. Priatna, "Mathematical Interactive Multimedia to Improve Mathematical Reasoning Ability of Senior High School Students," Advance in Soc. Sci. Ed. and Hum. Research, vol. 57, pp. 45, 2016 [1st ICMSEd, 2016].

[4] R. Al-Azawi, F. Al-Faliti, and M. Al-Blushi, "Educational Gamification Vs. Game Based Learning: Comparative Study," Int. J. of Innovation, Management and Technology, vol. 7, no. 4, pp. 132, Agust 2016.

[5] Y.K. Juan, and T.S. Chao, "Game-Based Learning for Green Building Education," J. of Sustainability, vol. 7, pp. 5605, May 2015.

[6] Rusman, D. Kurniawan, and C. Riyana, Pembelajaran Berbasis Teknologi Informasi dan Komunikasi: Mengembangkan Profesionalitas Guru, Jakarta: Rajawali Pers, 2011.

[7] Y. Roza, Kartini, A. Adnan, and Habiburrahman, "The Development of Interactive Computer-Based Madia for Learning Probability Subject in

Mathematics Class,” Advances in Soc. Sci. Ed. and Hum. Research, vol. 100, pp. 70, 2017 [5th SEA_DR International Conference, 2017].

[8] M. T. Gaydos, and K. D. Squire, "Role Playing Games for Scientific citizenship," Cult. Stud. of Sci. Educ., vol 7, pp. 823, 2012.

[9] S. M. Irham, Mawardi, and B. Oktavia, "The Development of Guided Inquiry-based Worksheet on Colligative Properties of Solution for Chemistry Learning," Advance in Soc. Sci. Ed. and Hum. Research, vol. 57, pp. 38, 2016 [1 st ICMSEd, 2016].

[10] M. J. A. Rahman, M. A. H. Ismail, and M. Nasir, "Development and evaluation of the effectiveness of computer-assisted physics instruction," Int. Educ. Stud., vol. 7, no. 13, pp. 14-22, 2014.

[11] J. Vanden Akker, R. M. Branch, K. Gustafson, N. Nievenn, and T. Plomp, Design Approaches and Tools in Education and Training. London: Kluwer Academic Publishers, pp. 126, 1999.

[12] E. P. Widyoko, Evaluasi Program Pembelajaran. Yogyakarta: Pustaka Pelajar, 2009.

[13] Z. Arifin and A. Setyawan, Pengembangan Pembelajaran Aktif dengan ICT. Yogyakarta: Skripta Media Creative, pp. 94, 2012.

[14] B. R. Hergenhahn and M. H. Olson, Theories of Learning, Edisi Ketujuh. Editor: T. Wibowo, Jakarta: Kencana, pp. 320, 2008.

[15] Ignas, RPG Maker VX Ace. Semarang: Wahana Komputer, 2014.

[16] A. Arsyad, Media Pembelajaran, Rajawali Press: Jakarta, pp. 175-176, 2009.

[17] N. H. Waryanto, Modul Pelatihan Kegiatan Pelatihan Penyusunan Materi Soal Matematika Interaktif Berbasis Web dengan Menggunakan Perangkat Lunak Bantu Articulate Quiz Maker 2.1 Bagi Guru Sekolah Menengah. Yogyakarta: Pendidikan Matematika FMIPA UNY, pp. 5-7, 2008.

[18] Trianto, Mendesain Model Pembelajaran Inovatif-Progresif, Konsep, Landasan, dan Implementasinya pada Kurikulum Tingkat Satuan Pendidikan (KTSP). Jakarta: Prenada Media Group, pp. 242, 2009.

[19] Y. Yamasari, "Pengembangan Media Pembelajaran Matematika Berbasis ICT yang Berkualitas,” Seminar Nasional Pasca Sarjana X. Surabaya: ITS, pp. 4, 2010.

[20] O. Hamalik, Kurikulum dan Pembelajaran. Jakarta: Bumi Aksara, pp. $170,2005$. 